\title{
Who Owns Education? Cleavage Structures in the Partisan Competition over Educational Expansion
}

\author{
MARIUS R. BUSEMEYER, SIMON T. FRANZMANN and JULIAN L. \\ GARRITZMANN
}

The literature on the partisan foundations of education policies leads to ambiguous expectations with regard to the predominant cleavage structures in party competition on this topic. There is disagreement as to whether leftist or rightist parties are responsible for increasing spending on education, while others claim that educational expansion has become a consensual topic. This paper analyses the cleavage structure of party competition over the topic of educational expansion, relying on data from the Compara tive Manifesto Project. It identifies political parties as 'issue owners' and 'issue ignor ers', respectively, and finds considerable variation with regard to cleavage structures of party competition between countries and across time. One tentative conclusion from the analysis is that policy legacies play an important role in shaping cleavage structures.

For a long time, the study of education was a 'neglected field' in political science (Jakobi et al. 2009; see also Iversen and Stephens 2008). Recently, however, scholarly interest in the politics and policies of human capital formation has increased significantly (for a comprehensive overview, see Busemeyer and Trampusch 2011). An important strand within this literature is concerned with analysing the relationship between partisan politics and policy output, in particular education spending (Ansell 2008, 2010; Boix 1998; Busemeyer 2007, 2009b; Jensen 2011; Schmidt 2007; Wolf and Zohlnhöfer 2009). More recently, scholars have started to probe the dynamics of individual education policy preferences (Ansell 2010: 119-63; Busemeyer 2010; Busemeyer et al. 2009, 2011), although research in this area is still much more exploratory than in the case of policy outputs. Completely missing so far, however, are studies on the 'middle' element between individual policy preferences and policy outputs, i.e. party preferences. The only exceptions are Ansell (2010) and Jakobi (2011), who

Correspondence Address: marius.busemeyer@uni-konstanz.de; simon.franzmann@uni-duesseldorf.de; julian.garritzmann@uni-konstanz.de 
provide some initial evidence on the relationship between education and elections by analysing party preferences in election programmes. In this paper, we go a step further by identifying patterns of partisan conflict over education by analysing differences between parties, i.e. issue-owners and issue-ignorers.

The study of parties' election programmes on education is significant, because it provides a better understanding of the linkages between the different stages in the policy-making process, i.e. preferences, programmes and policies. Prima facie, it could be expected that individual preferences should be reflected in partisan programmes, which in turn shape policies. However, it might also be the case that partisan programmes reflect a ubiquitous consensus on the desirability of educational expansion on the level of political discourses, while at the same time partisan conflicts over the distribution of public spending lead to significant partisan differences in output (Jakobi 2011: 7).

While the literature on the politics of education has largely ignored the study of party manifestos, the extensive literature on party manifestos in turn is not concerned with studying education explicitly. Instead, various items with redistributive implications (i.e. social and education policies) are often grouped together to construct an underlying left-right continuum (Dinas and Geminis 2010; Franzmann and Kaiser 2006; Gabel and Huber 2000; Klingemann 1995; Laver and Budge 1992; Pelizzo 2003). This approach is useful in many ways, but it neglects the study of patterns and cleavage structures specific to policy fields and countries.

Linking the literature on the politics of education with scholarship on party manifestos, our central research question is whether the issue of educational expansion is a consensual issue or a contested partisan issue, and if it is contested, which parties are the 'issue-owners'. Given the limited empirical knowledge in this field, our paper is to a certain extent explorative. In the next section, we will present and discuss various expectations and hypotheses regarding our research question, drawing from different literatures. After that, we discuss the data, methods and underlying concepts. The subsequent section will then engage in a detailed empirical analysis of parties' election programmes in 18 countries, using the Comparative Manifestos Project (CMP) Dataset as the data source. We demonstrate that the observed patterns are much more complex than suggested by the pertinent literature. We show that the willingness to expand education can be a consensual issue as well as a topic owned by leftist and rightist parties, depending on the country- and time-specific context. More substantively, we find that in contrast to Jakobi's (2011) claim, partisan contest about the expansion of education has not diminished, but instead increased over time. Furthermore, we find that in some countries the issue of education is 'owned' by the political right, whereas in others it is owned by the political left. Our tentative explanation for this pattern emphasises the importance of policy legacies: in countries with comprehensive education systems (e.g. Sweden), the right is more likely to own education, whereas the reverse patterns holds in countries with more segregated education systems (e.g. Germany). Policy legacies in education, in turn, might be related to differences in how the historical 
conflict between the church and the state over education played out. However, there are important exceptions to this pattern, which we will discuss along with avenues for future research in the conclusion.

\section{Literature Review and Theoretical Expectations}

This paper addresses two literatures that, so far, have remained quite disconnected from each other. First, the literature on the partisan politics of education provides theoretical arguments about the preferences and policies of distinct parties and party families. However, patterns of partisan conflict depend on the interaction of different parties, i.e. partisan competition. We therefore combine the traditional view of party difference theory with the issue-based concept of party competition (Franzmann 2011; Green-Pedersen and Mortensen 2010).

\section{The Partisan Politics of Educational Expansion}

The existing literature on the partisan politics of educational expansion provides ambiguous, at times even contradictory expectations with regard to our central research question, i.e. whether educational expansion is a consensual or partisan issue. Because there are very few studies on the role of education in party manifestos, we derive our theoretical expectations by inferring from studies of policy output and individual preferences, the two adjacent stages in the policy cycle.

A first perspective is represented by Jakobi (2011) - one of the two studies that explicitly analyse support for educational expansion using the manifesto data set. She argues that educational expansion has become a consensual issue supported by all mainstream parties. She makes several important observations: first, the importance of educational expansion (measured as the share of positive mentions in party manifestos) increases over time. Second, it is one of the issues least opposed, i.e. there are virtually no parties that demand the retrenchment of education. Third, differences between parties of the left and the right in their promotion of educational expansion were significant in the early post-war period, but strongly diminish over time (Jakobi 2011: 12-16). Jakobi's interpretation of these findings is rooted in Meyer's notion of the emergence of a 'world society' (Meyer et al. 1997). According to this approach, the expansion of educational opportunities in the last decades is an important part in the institutionalisation of a world society. Thus, widespread support for educational expansion is due to its 'broad and societal appeal' (Jakobi 2011: 6), stemming from its purported role in stimulating growth, reducing crime etc.

Ansell's (2010) study mirrors the findings of Jakobi (2011) in the sense that he too finds widespread support for the expansion of education in the manifesto data. More specifically, Ansell identifies an 'inverse-U' relationship (Ansell 2010: 137) with the mainstream parties of the centre (social democrats and liberals) being most supportive of educational expansion compared to 
the parties on the extremes of the political spectrum. However, studying the relationship between party manifestos and policy output, Ansell (2010) argues that the general ideological stand of a political party is a better predictor of output in terms of spending than the rhetorical appeal to educational expansion in manifestos. Hence, Ansell finds consensus on the rhetorical level, but partisan conflict with regard to output. In a similar vein, Busemeyer (2007: 602-3) finds that the positive impact of government participation of social democrats on levels of public education spending weakens and disappears for the more recent period of the 1990s. There are many possible reasons for this such as the increasing pressures of globalisation (Busemeyer 2009a; Kittel and Obinger 2003). However, the weakening of the partisan effect could also be due to the fact that even parties of the right promote educational expansion because of the widespread support of this issue on the micro-level resulting in a consensus on education on the party level.

Looking at individual preferences, the expectation of widespread support for educational expansion is partly confirmed. Figure 1, based on survey data from the ISSP Role of Government IV survey (2006), shows the variation in the support for 'more' or 'much more' public spending on education in OECD countries. This figure shows that despite significant cross-national variation, in almost all countries, large or very large majorities of respondents are in favour

FIGURE 1

PERCENTAGE SHARE OF RESPONDENTS BEING IN FAVOUR OF 'MORE' OR 'MUCH MORE' GOVERNMENT SPENDING ON EDUCATION

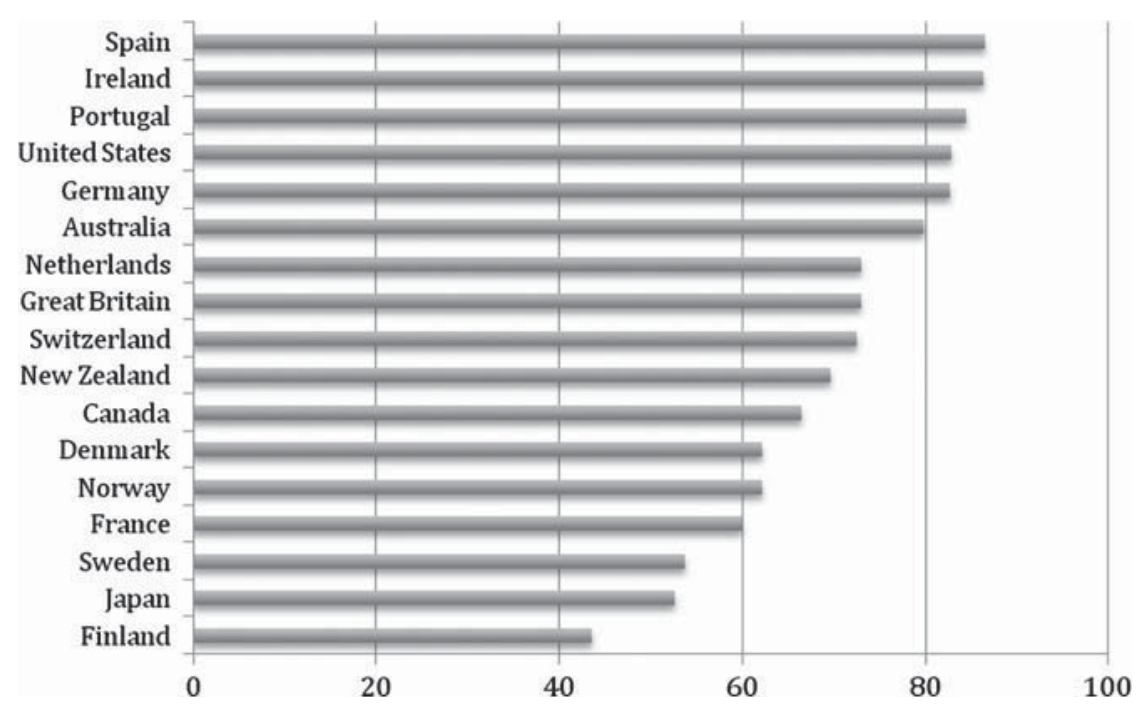

Source: ISSP Role of Government IV Data, 2006. 
of increasing education spending. Hence, political parties appealing to the median voter have a strong incentive to promote educational expansion.

A second theoretical perspective would expect educational expansion to be a topic owned by the political left. While partisan effects might have decreased in the recent period, Busemeyer (2007), Castles (1998) and Schmidt (2007) argue that they have been more important in the long term and the formative phase of contemporary education regimes in the post-war decades (see also Iversen and Stephens 2008). These studies show that government participation of the left is associated with a significant expansion of public spending on education. Following Boix (1998), social democrats in government are more likely to expand public education than conservative parties, because investments in human capital formation are aimed at reducing long-term socio-economic inequalities. Furthermore, whereas partisan effects seem to be muted in the case of total public education spending, government participation of social democrats remains a strong determinant of spending on higher education (Busemeyer 2009 b), i.e. a sector of the education system with potential for expansion.

Initial evidence from the micro level reinforces the notion that support for educational expansion is associated with partisan ideologies. Relying on survey data from Switzerland, Busemeyer, Cattaneo and Wolter (2011) show that individuals who identify with the political left are significantly more likely to support public spending on education and oppose tuition fees for higher education. Ansell (2010: 134) and Busemeyer (2010), using the ISSP data, also find that partisan supporters of the left are more likely to be in favour of increases in public education spending, independent of their individual socio-economic backgrounds.

Thus, instead of being a consensual issue, the second theoretical perspective suggests a considerable degree of partisan conflict over the expansion of education. Because increasing investments in education tend to benefit those left out before, the expansion of education is believed to be an issue pushed by the political left.

However, there are also good arguments for why educational expansion could be associated with the political right. Jensen (2009, 2011), for example, argues that investments in education have a smaller impact on redistribution than other kinds of social policies. Investments in higher education could therefore be used 'as a means ... to provide social protection' (Jensen 2009: 2), used by right-wing governments in order to cushion negative de-industrialisation effects on their electorate. He finds that left-wing governments are positively associated with spending on higher education when de-industrialisation is low, but that '[a]t high levels of de-industrialisation, right-wing governments become significantly associated with tertiary education spending' (Jensen 2009: 15). Moreover, Jensen argues that leftwing parties do not per se have a 'special preference for high levels of educational spending' (Jensen 2011: 416) and rather support welfare policies that are more redistributive than education. In contrast to most existing literature, he does not find a positive effect of left parties on education spending 
and even reports a negative effect once the variable for the partisan composition of the government is lagged (Jensen 2011: 425).

Taking this idea one step further, Ansell $(2008,2010)$ explicitly contends that the expansion of higher education is promoted by the political right, not the political left, when enrolment rates in higher education are low and access is limited (Ansell 2008: 207). The argument underlying this hypothesis is that the traditional constituencies of rightist parties in the (higher) middle and the upper income classes are more likely to support educational expansion, in particular in higher education, because they expect to benefit from increased investments more than other electoral constituencies. ${ }^{1}$ Further evidence for a positive effect of government participation of rightist parties on education spending is provided by Wolf (2006) for the case of German Länder.

Given these conflicting hypotheses, our strong expectation is that country contexts and policy legacies will play a crucial role in shaping the political competition over educational expansion. A shortcoming of the study by Jakobi (2011) is that she is only concerned with the 'average' effect over all countries included in the data set. The same critique applies to Ansell's work (2010) because he is only interested in differences across party families and hence uses aggregated data as well. It might, however, be that the aggregated data blends over major variation on a less aggregated data level (i.e. the country level) as well as changes across time. It could be expected that educational expansion is a consensual issue in one country, whereas it is an issue of the left in a second and identified with the right in a third country.

More specifically, we would expect partisan consensus on educational expansion to prevail in the earlier stages of the historical development of education systems, when parties of different stripes are more likely to agree on the necessity to expand educational opportunities. With the institutionalisation of different kinds of education systems in the immediate post-war decades, partisan conflict over educational expansion is likely to increase. In some countries, in particular the Scandinavian countries, the predominance of the left led to the establishment of the 'Nordic Model of Education' (Oftedal Telhaug et al. 2006), aimed at reducing educational and social inequalities by establishing comprehensive education systems. Over time, political parties of the right may have started to challenge the 'leftist consensus' on comprehensive education, e.g. by promoting the establishment of quasi-private, independent 'free schools' as the non-socialist government coalition in Sweden did in the 1990s (Klitgaard 2007). In countries, where conservative policy legacies prevail, the logic of partisan competition might be reversed.

Moreover, policy legacies are likely to be related to differences in how the historical conflict between the church and the state over education played out. A common argument in the literature is that a religious heritage of Catholicism has slowed down the expansion of education systems (Castles 1989, 1994; West and Woessmann 2010), because of the intense conflict between the Catholic Church and the state over the provision of education. Furthermore, countries with a strong heritage of Christian democratic government in the 
post-war decades and conservative welfare state regimes, such as Germany, Austria and the Netherlands, often have segregated education systems with early tracking and limited access to higher levels of education (Busemeyer and Nikolai 2010). In these contexts, we would therefore expect parties of the political left to be the owners of the issue of educational expansion. Countries with a strong Protestant heritage, in contrast, are believed to be more supportive of the expansion of education (see Manow and van Kersbergen 2009 for the case of welfare state policies more generally). In the Scandinavian countries, statist Lutheran Protestantism might have promoted the establishment of comprehensive and state-centred education systems, which in turn triggered a counter-movement on the part of the political right.

\section{Issue Owners and Issue Ignorers in Party Competition}

Before we begin the empirical analysis, we first discuss the concept of issue ownership in the context of the literature on party competition as this concept forms the theoretical framework for our empirical analysis. In general, many studies on party competition can be divided roughly into two camps with regard to their theoretical background: 'salience theory' or 'positional/confrontational theory'. These two theories differ mostly in their expectations about how parties compete on policies. Salience theorists (Budge 2001a, 2001b; Budge and Farlie 1983; Budge and Robertson 1987; Robertson 1976) hold the opinion that parties do not compete directly with each other by taking opposing views on each issue. Rather they are expected to 'compete by accentuating issues on which they have an undoubted advantage' (Budge and Robertson 1987: 391). This expectation was derived, on the one hand, inductively from studies observing that parties do not mention their rivals (and their proposals) in their programmes (Budge and Farlie 1983; Robertson 1976). On the other hand, it is grounded in Donald Stokes' notion of 'valence issues'. He

distinguished position issues, on which parties or leaders are differentiated by their advocacy of alternative positions on an ordered dimension, from valence issues, on which parties or leaders are differentiated not by what they advocate but by the degree to which they are linked in the public's mind with conditions or goals or symbols of which almost everyone approves or disapproves. (Stokes 1992: 143; emphasis original)

Following this, the orthodox view of salience theory claims that parties propose the same ways of problem solving for an issue and do not distinguish themselves by their position but by the emphasis they place on particular issues. $^{2}$ In line with this argument, it is assumed that political parties tend to 'emphasize the importance of those issues where the party is ideologically committed and hence most trusted by electors' (Budge 2001b: 58).

A central concept within salience theory is thus 'issue ownership'. This concept means that parties can 'own' certain topics as they are linked in the 
public's mind with credible solutions to particular policy problems. In turn, they compete by emphasising the topics they 'own' over and over again. The effect is that ' $[\mathrm{r}]$ ather than promoting an educational dialogue, parties talk past each other' (Budge and Farlie 1983: 24). As a counterpart to the concept of 'issue-ownership', we propose to consider 'issue ignoring'. We define those parties as 'issue-ignorers' that systematically pay less attention to an issue than other parties. From our point of view, issue-ignoring is just a logical consequence when we talk about issue-ownership. The concept of issue-ignoring can be a helpful analytical tool to investigate and describe party competition more precisely. As electoral campaigns are fights for control over the political agenda (Green-Pedersen and Mortensen 2010), the interaction between owners and ignorers shapes patterns of partisan competition. Analytically, we consider an issue-market mechanism - i.e. voters only care about partisan manifestos, abstracting for the time being from candidate or clientelistic influences (Franzmann 2011). To our knowledge, the concept of issue-ignoring is spelled out here for the first time. A similar idea, however, is discussed in Meguid's (2008) analysis of mainstream parties' reactions to niche party success. She states that one possible strategy for the mainstream party is dismissive behaviour towards the issues owned by niche parties. However, Meguid formulates her theory in a positional framework, which is more rooted in the micro-level of partisan competition compared to our macro approach.

In our view, the perspective of salience theory and the notions of issue-ownership and issue-ignoring are particularly suited to study partisan conflict over educational expansion, as investments in education are often regarded as 'an archetypical crowd-pleaser' (Ansell 2010: 136). In such a policy field, it makes more sense to distinguish political parties by how much emphasis they put on the issue rather than whether they are in favour or against educational expansion.

\section{Data, Concepts and Methods}

In this section, we first present several approaches to measure parties' policy preferences, followed by a brief discussion of the data we use, its underlying measurement concept and the methods applied.

\section{Measuring Policy Preferences with Manifesto Data and Potential Criticism}

A milestone project for collecting data on issue stances is the work of the Manifesto Research Group/Comparative Manifestos Project (MRG/CMP). ${ }^{3}$ The CMP (Budge et al. 2001; Klingemann et al. 2006; Volkens et al. 2011) codes manifestos manually and records them statistically. In a first step, country experts divide the documents into smaller coding units in terms of content, called quasi-sentences, so that each quasi-sentence contains a single policy statement. A grammatical sentence can - if necessary - be divided into several quasi-sentences. Second, each of these quasi-sentences is classified into one (and just one) of 56 predefined issue categories (e.g. 'Market Regulation: Posi- 
tive', 'Multiculturalism: Positive', 'Military: Positive') or a residual category. In a third step, the number of sentences in each category is added up and divided by the absolute number of all coded sentences to achieve a measure of the relative frequency with which each issue is mentioned in the party programme. ${ }^{4}$ On the basis of these frequencies (percentages), which are called saliences, ${ }^{5}$ parties can be located in a policy space, they can be compared against one another, and changes over time can be investigated.

Compared to other approaches, the CMP data set, in our view, is best suited to answer our research question. Empirically, it offers data for elections between 1945 until 2010 covering by now 3,334 manifestos for 840 parties, enabling comparisons across countries, across party families and across time. One of the coding categories the CMP offers is the item 'Education Expansion' (per506), which is characterised as: 'Need to expand and/or improve educational provision at all levels' ${ }^{6}$ This variable is very fitting to identify patterns of partisan competition over education. ${ }^{7}$ Moreover, Budge and Meyer (forthcoming) have demonstrated recently that the variable used ('Education Expansion', per506) works as a satisfactory measurement of issue salience (while the opposing counterpart, 'Education Limitation' per507 does not).

From a theoretical perspective, the CMP data corresponds to our research question as well, since the underlying measurement concept is grounded in sal ience theory. The Comparative Agendas Project data (CAP; Baumgartner et al. 2011) would also be in line with our theoretical approach. But CAP does not yet provide data for such a long time period and not for all West European countries. Approaches suitable to determine general party policy positions using documents such as Wordscores (Laver et al. 2003) and Wordfish (Slapin and Proksch 2008) do not provide data on single issues either, nor do they cover the same time period. The latter is also true for expert judgements. Therefore we see no real alternative to the CMP data.

We should, however, point out several disadvantages of the CMP data and potential criticisms. On a more general level, the CMP is criticised for using election programmes to derive parties' policy preferences. Some authors hold the opinion that these consist only of pure rhetoric and do not help us to discover what a party 'really' stands for. A second line of criticism agrees with using party manifestos as a data source, but is concerned with the way the CMP uses and interprets manifestos. Especially advocates of a position theory of party competition have criticised the CMP's coding approach and were concerned with possible bias in the data, for example the lack of statements on their uncertainty (Bakker et al. 2006; Benoit et al. 2009; Laver and Benoit 2007; Lowe et al. 2011). Other critiques in this line point to the selection of manifestos and the coding procedure, reporting for example variations in the number of coded (and conversely uncoded) sentences per manifesto and partly arbitrary selection of manifesto texts (e.g. Hansen 2008 for the case of Denmark).

Of course the reliability and validity of this data has to be (and has been) discussed critically. Besides, many others, especially Benoit and Laver (2007), Budge et al. (2001), Klingemann et al. (2006), Laver and Garry (2000), Peli- 
zzo (2003), and Volkens (2006, 2007), summarised criticisms and discussions on several points. For our research project it suffices here to say that tests of the coders attest a high degree of reliability (Volkens 2009), that the results of the CMP correlate (highly) with other measurements (Volkens 2006) and that they were supported in further studies (see McDonald and Mendes 2001). As we cannot trace and evaluate the data quality of the CMP further here, we wish to stress two points once again: on the one hand, the CMP offers an ingenious and unique data source to conduct our research. On the other hand, the data has been criticised for several reasons and therefore should not be analysed and interpreted without caution.

Besides these general criticisms of party manifestos as a source of party stances, a more specific justification of our use of the CMP data to study education is in order. Firstly, some critics might question whether it is possible at all to consider single issues from the CMP data without reference or comparison to other issues. This critique overlooks that the data regarding frequencies (as a percentage of the whole manifesto) is always in comparison to other issue categories. In fact, analyses using single CMP issues can show interesting results (e.g. Nygård 2006). Secondly, it can be argued that the issue we use (per506), which is defined as 'Need to expand and/or improve educational provision at all levels', is too broad to measure substantive party programme contents on such a comprehensive and complex field as education. One problem of this operationalisation is that the definition includes demands for both expansion and improvement. Thus it remains unclear whether a party wants to reform the existing system in a particular way or whether it wants to expand educational opportunities. ${ }^{8}$ A second problem is that the broad definition does not distinguish between different educational sectors, although this issue is important for several of the authors reviewed above (e.g. Ansell 2008, 2010; Busemeyer 2009b; see literature review above). The political dynamics of the conflict over educational expansion might be very different depending on whether the conflict is about primary and secondary education or tertiary education. Ideally, we would have a more fine-grained coding scheme distinguishing between the parties' preferences on the different education sectors. Unfortunately, this data is not available and it is not feasible to disaggregate the CMP data. Despite these problems, we are convinced that the issue we use can serve as a good measure to identify the broad cleavage structures of party competition over education. Moreover, as we are not interested in substantive party positions in this article but in patterns of party competition on education and on issue ownership, it analytically does not make a difference whether parties propose expansion or reform, as it is only important for our purpose here that they mention and stress education policies at all.

A final point of criticism is that our analysis is based on party manifestos on the national level, whereas in a number of countries the most important level of decision-making for education policy is the subnational level. To this our reply is threefold. The first and most obvious reason is one of data availability. Although some efforts have been made to code manifestos at the subnational 
level (e.g. for Germany: Bräuninger and Debus 2008; Schmitt 2008), to our knowledge no comparative data set of (manually coded) subnational party manifestos exists so far that would equal the scope and the quality of the CMP data. Secondly, to a certain degree, we would expect parties at the subnational level to follow national parties in setting their policy priorities ('trickle-down effect'), in particular because we are dealing with a very broad and general policy goal (educational expansion). Thirdly, it could be argued that voters are not necessarily informed about the differences in policy priorities between national and subnational parties, especially when politicians from the national level are highly visible in the media and discuss education policy even in cases where authority mainly is located at the subnational level. Finally, one could argue that the criticism only limits the scope of our results in the sense that we look at patterns of partisan competition at the national level, not necessarily a given country as a whole, although we would contend that even in cases where education policy is decided at the subnational level, party manifestos of national party organisations are a valid proxy for the purpose of our research.

\section{Methods: How We Use the CMP Data to Investigate Party Competition on Education}

In our analysis we concentrate on countries in Western Europe, because these countries have a similar socio-cultural and historical background and therefore similar political cleavage structures (compared to non-European countries). Otherwise, we would not be able to distinguish between patterns of partisan conflict evoked by different contexts from patterns really linked to partisan conflict. Hence, we analyse the following 18 countries: Austria, Belgium, ${ }^{9}$ Denmark, Finland, France, Germany, Greece, Iceland, Ireland, Italy, Luxembourg, Netherlands, Norway, Portugal, Spain, Sweden, Switzerland and the United Kingdom.

For these countries, we have included all parties from the data set that at least provide two data points, which means that the particular party has successfully entered the parliamentary arena twice. In other words, we exclude those parties from the dataset for which only a single data point exists. Moreover, we only included those parties that compete on the national level; hence, parties focusing only on regional affairs in national elections have been excluded. ${ }^{10}$ For these countries and parties we included all possible time points from the latest CMP version. ${ }^{11}$ The time period covered is from 1945 (respectively the year when the first democratic elections were held) until 2010, depending on data availability. ${ }^{12}$

In order to investigate party competition on education using the CMP data and its underlying theory, we need to find out whether, first, the competition is contested or not (i.e. consensual), second, which party (or parties) own(s) and, third, which party (or parties) ignore(s) the issue, and, finally, to which political wing (left or right) and party family the issue-owner(s) and issue-ignorer(s) belong. In order to determine the degree of conflict over the issue 'education 
expansion', we apply a five-step procedure that essentially builds around simple dummy regressions as suggested by Franzmann and Kaiser (2006).

First, as we are interested in the patterns of party competition on education in the countries analysed, one condition for successfully applying our procedure is that parties tend to keep their programmatic profile over time without too many modifications. Walgrave and Nuytemans (2009) have shown for Western Europe that this is indeed the case. However, in some countries the issue character changed due to party system realignments. Therefore, in a first step, we divide the data set into subsets each time a new party successfully establishes itself in the parliamentary arena of a given country, i.e. each time it manages to $r$-enter parliament at least once. In a second step, we identify for each subset the party with the highest salience on 'education expansion' by simply reading off the respective values from the dataset. Third, we apply regressions using the parties' saliences on the 'education expansion' issue as the dependent variable, and a dummy for each party as independent variables. The party with the highest salience detected in the first step serves as the baseline category (reference category), which is the constant in the regression. In a fourth step we analyse the regression results concentrating on the ANOVA t-test results between the intercept (constant) and the factors in order to determine significant differences between the parties in their particular issue emphasis. ${ }^{13}$ We are not interested in the coefficients or the R-square, but in the pairwise t-tests of each factor compared to the baseline. Two results are possible here: if we observe a significant difference (at the 5 per cent level), we can conclude that this difference in issue salience is systematically linked to the different parties. We then infer that the issue 'education' is a contested issue in the particular country and time period analysed. If, on the other hand, we cannot detect a significant difference between any factor and the intercept, we empirically cannot show that differences in issue saliences are non-random. In this case, we infer that the issue is non contested. In case the issue is contested for a given country and time period, we identify the primary issue-owner as the party with significantly higher levels of salience. In case we find no significant differences between the party with the highest salience (the primary issueowner) and other parties, several parties can become the issue-owners as long as there remains a significant difference between the group of issue-owners and another group of issue-ignorers (otherwise the issue would simply be classified as non-contested). Hence, issue-ignorers are parties with significantly lower levels of salience than the other parties. The last step of our calculations is that we repeat this procedure for each country (each subset).

\section{Empirical Results}

Overview: Some Descriptive Statistics

To start, we present some simple descriptive statistics. Both Ansell (2010) and Jakobi (2011) first calculate means across the whole data set, disregarding 
TABLE 1

DESCRIPTIVE STATISTICS

\begin{tabular}{lcc}
\hline & Education expansion (per 506) & Education limitation (per 507) \\
\hline$N$ & 1784 & 1784 \\
Missing & 0 & 0 \\
Mean & 3.7177 & 0.0651 \\
Standard deviation & 3.34330 & 0.46471 \\
Median & 3.3140 & 0.0000 \\
Minimum & 0.00 & 0.00 \\
Maximum & 30.30 & 13.80 \\
\hline
\end{tabular}

Source: Own calculations based on CMP data.

differences across countries, across party ideologies (party families) and across time. We reproduce these in Table 1 for our data set and moreover report standard deviations, minima and maxima (see also Tables A1 and A2 in the Appendix). The mean of education expansion is 3.72 on average, which means that almost 4 per cent of all coded sentences refer to education expansion. In comparison to all the other 55 CMP issues from the classification scheme, education expansion shows the eighth highest value. ${ }^{14}$ Education limitation, on the other hand, is the issue least mentioned in the whole data set ( 0.07 per cent). In fact, of the 1,784 manifestos considered here, 1,652 (92.6 per cent) do not mention 'Education Limitation' at all and only eight programmes have a higher value than 2.8 per cent. Hence, a first observation is - as Jakobi (2011) pointed out - that education is one of the topics least opposed. This is some initial evidence that the perspective of salience theory is adequate for our analysis. Additional descriptive analyses - not reported here for reasons of space ${ }^{15}$ - show that weighting the data by vote share for each party yields higher average values for the salience of education, i.e. parties with larger vote shares emphasise educational expansion more than smaller parties (cf. Table A2 in the Appendix, and Garritzmann 2009).

\section{Analysing Cleavage Structures in the Partisan Competition over Education}

In contrast to Jakobi (2011) and Ansell (2010), we disaggregate the data in order to determine the variation in the partisan conflict over education across countries and over time. Table 2 provides a summary of our findings. The second column includes information on whether partisan conflict over education has been contested or not. We find three different constellations: First, in most party systems (13 out of 19 , which equals about 68 per cent) the issue of educational expansion is contested during the whole period of analysis, i.e. we can identify issue-owners and issue-ignorers. Second, we find a non-contested pattern of party competition only in two systems (Spain and Wallonia). ${ }^{16}$ Third, in four systems (Austria, Flanders, Germany and Ireland) we first observe that education is not contested, but $i s$ contested later on. It is striking that we do not find the opposite pattern, i.e. competition that is first contested and then non-contested. These results put into question the claim that educational expansion is a matter of consensus between parties (more on changes over time will be said below). 


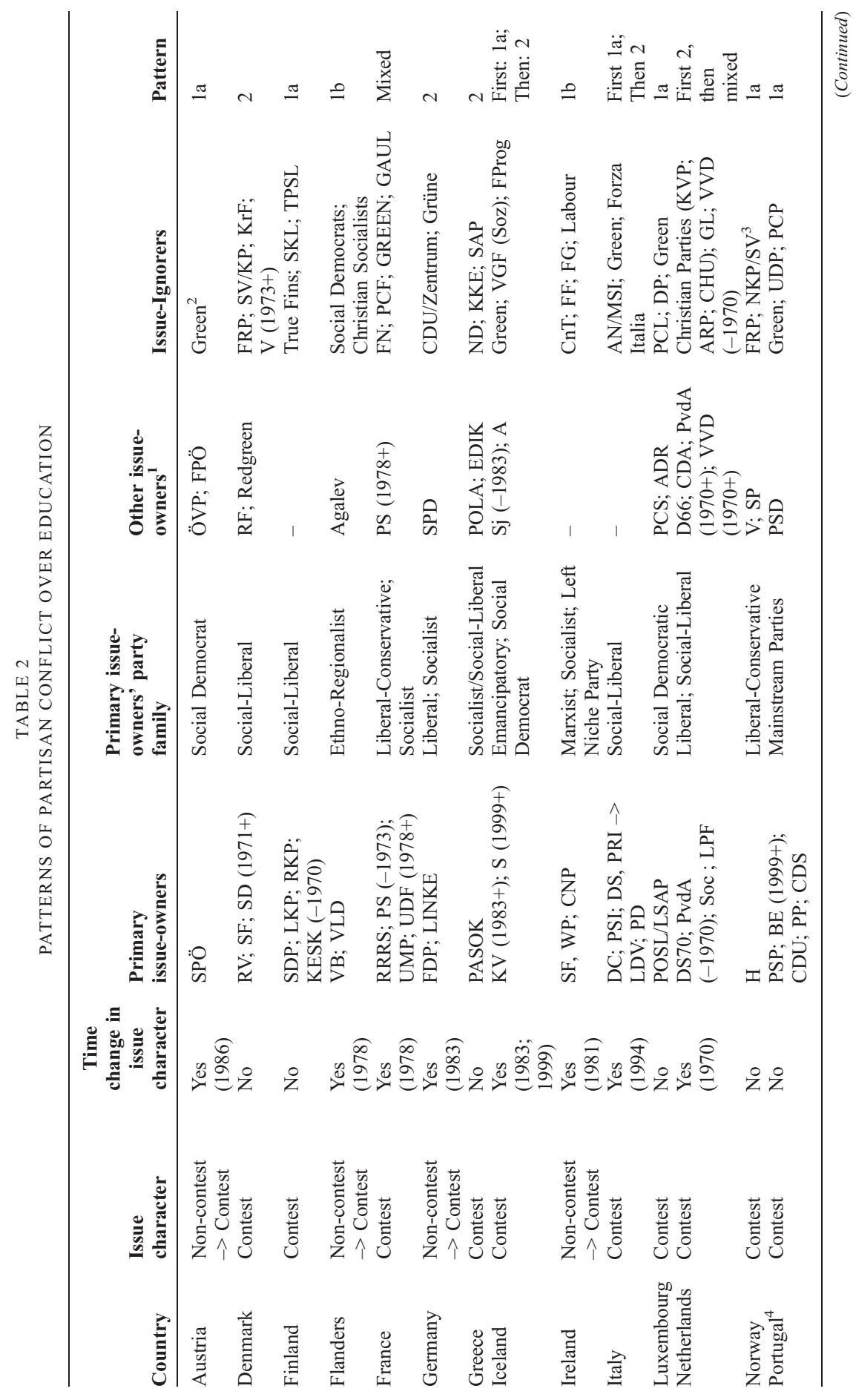




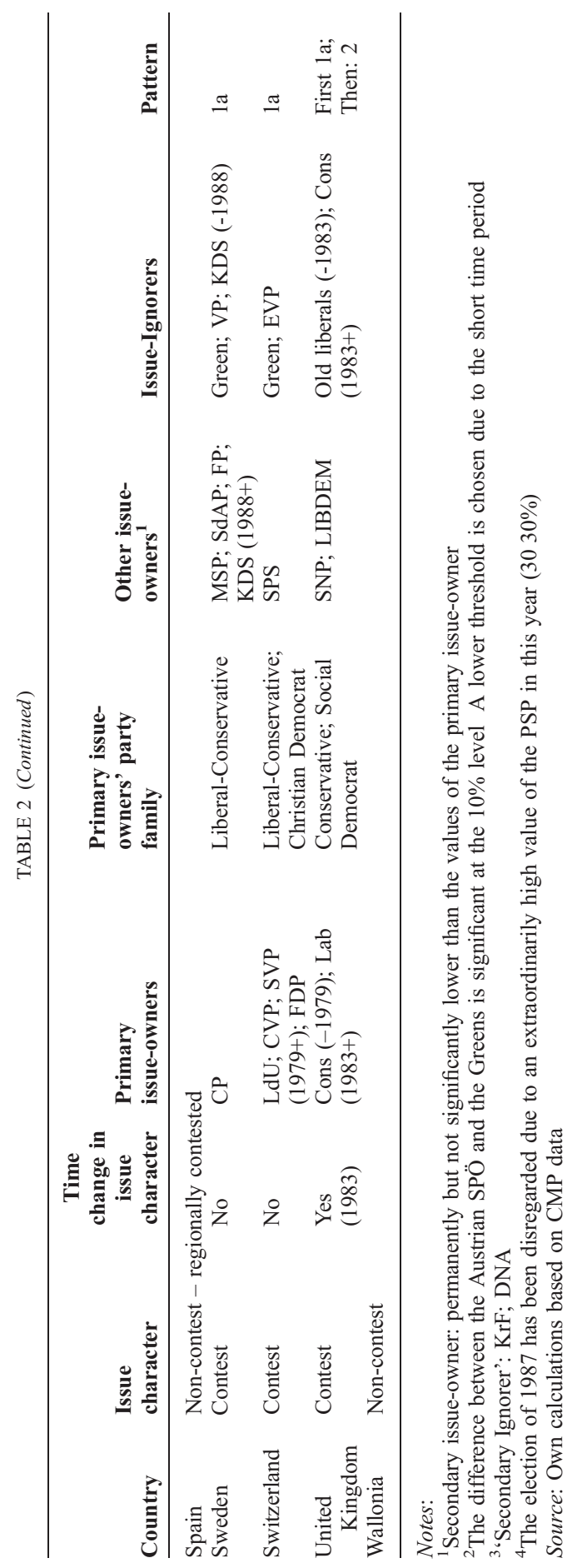


In a second step, we now identify issue-owners and issue-ignorers of education expansion, which, as argued above, only makes sense when the issue is contested (hence we disregard Spain and Wallonia for now). Columns 4 to 7 of Table 2 present detailed information on our findings. First, we list the primary issue-owner(s) and their party families. We then report whether we find other issue-owners, i.e. parties that emphasise education policies on a permanently high level but still show significantly lower values than the primary issueowners. Finally, we name those parties that we identified as issue-ignorers.

A couple of observations can be made here: first, across the whole sample of European countries, the topic of educational expansion is mostly owned by social democratic parties with a strong liberal branch or by liberal parties. However, within the group of liberal parties, it is important to distinguish between different branches (economic versus social liberalism). Educational expansion is favoured mostly by parties from the liberal-radical branch (Smith 1988; Steed and Humphreys 1988). Second, there are important exceptions to this general pattern. In countries with strong conservative parties with a liberal tradition or without a strong Catholic tradition, parties of the right own education. This

TABLE 3

CHANGES IN CONTEST OVER EDUCATIONAL EXPANSION IN 18 COUNTRIES OVER TIME

\begin{tabular}{|c|c|c|c|}
\hline Time period & $\begin{array}{l}\text { Contested } \\
\text { owned by left }\end{array}$ & Non-contested & $\begin{array}{l}\text { Contested } \\
\text { owned by right }\end{array}$ \\
\hline 19451969 & DEN; FRA; FIN; ICE; LUX; NDL & $\begin{array}{l}\text { AUT; FLA; GER; } \\
\text { IRL; ITA; WLA }\end{array}$ & $\begin{array}{l}\text { GBR; NOR; } \\
\text { SWE; SWI }\end{array}$ \\
\hline $\begin{array}{l}\text { (Without } \\
\text { GRE; POR; } \\
\text { ESP) }\end{array}$ & $6(37.5 \%)$ & $6(37.5 \%)$ & $4(25 \%)$ \\
\hline \multirow[t]{2}{*}{19701980} & $\begin{array}{l}\text { DEN; FIN; GRE; ICE; LUX; NDL; } \\
\text { POR }\end{array}$ & $\begin{array}{l}\text { AUT; ESP; FLA; } \\
\text { GER; IRL; ITA; } \\
\text { WLA }\end{array}$ & $\begin{array}{l}\text { FRA; GBR; } \\
\text { NOR; SWE; } \\
\text { SWI }\end{array}$ \\
\hline & $7(36.8 \%)$ & $7(36.8 \%)$ & $5(26.3 \%)$ \\
\hline \multirow[t]{2}{*}{19811991} & $\begin{array}{l}\text { AUT (1986 ); DEN; FIN; GBR; } \\
\text { GER; GRE; ICE; IRL; LUX; NDL; } \\
\text { POR }\end{array}$ & ESP; ITA; WLA & $\begin{array}{l}\text { FLA; FRA; } \\
\text { NOR; SWE; } \\
\text { SWI }\end{array}$ \\
\hline & $11(57.9 \%)$ & $3(15.8 \%)$ & $5(26.3 \%)$ \\
\hline \multirow[t]{2}{*}{1992} & $\begin{array}{l}\text { AUT; DEN; FIN; GBR; GER; GRE; } \\
\text { ICE; IRL; ITA; LUX; NDL; POR }\end{array}$ & ESP; WLA & $\begin{array}{l}\text { FLA; FRA; } \\
\text { NOR; SWE; } \\
\text { SWI }\end{array}$ \\
\hline & $12(63.2 \%)$ & $2(10.5 \%)$ & $5(26.3 \%)$ \\
\hline
\end{tabular}

Notes: Countries are printed in bold when they moved from one category into another. Countries that remain in the same category the whole time are underlined. Notice that the time periods have different durations. For reasons of simple legibility, we opted for this summary. No information is lost due to fewer categories since the patterns within each period define remain constant.

Source: Own calculations using the dummy regression-procedure described above based on CMP data. 
pattern can be observed in the UK, Norway, Sweden and Switzerland as well as in France and Flanders for the more recent period since the 1980s.

Table 3 contains more detailed information on changes in the cleavage structure across time. It has three categories: 'contested and owned by the left', 'non-contested', and 'contested and owned by the right'. Below the country names, we report the absolute and relative number of countries per category for each time period. The important thing to notice is how the middle category (counting the number of countries with a non-contested pattern for each period) empties out over time. While in the 1950s and 1960s, 37.5 per cent of all countries showed no contest on education expansion, this number is reduced drastically to 10.5 per cent for the last sub-period (1990s until today). This is strong evidence that the debate about educational expansion has become more contested and not less as suggested by Jakobi (2011).

As party competition on average gets more contested over time, it is increasingly owned by the political left. The last column of Table 3 shows that the number of party systems, in which right-wing parties emphasise education most, remains more or less stable over time (around 25 per cent). In Norway, Sweden and Switzerland, the issue is owned by right-wing parties during the whole period of observation. In contrast, the second column of Table 3 demonstrates impressively that the number of countries, in which left-wing parties

TABLE 4

AVERAGE VOTE SHARE OF THE ISSUE-OWNERS IN EACH PARTY SYSTEM

\begin{tabular}{lccc}
\hline Country & $\begin{array}{c}\text { Primary issue-owners' vote } \\
\text { share }\end{array}$ & $\begin{array}{c}\text { Other issue-owners } \\
\text { vote share }\end{array}$ & $\begin{array}{c}\text { Total issue-owners' } \\
\text { vote share }\end{array}$ \\
\hline Austria & 38.10 & 0 & 38.10 \\
Belgium & 33.13 & 10.41 & 43.54 \\
Denmark & 38.74 & 2.86 & 41.6 \\
Finland & 46.07 & 0 & 46.07 \\
France & 25.18 & 26.72 & 52.90 \\
Germany & 11.67 & 36.53 & 48.2 \\
Greece & 38.34 & 8.81 & 47.15 \\
Iceland & 14.41 & 49.85 & 64.26 \\
Ireland & 3.99 & 0 & 3.99 \\
Italy & 47.46 & 0 & 47.46 \\
Luxembourg & 29.45 & 38.97 & 68.42 \\
Netherlands & 17.65 & 75.89 & 93.54 \\
Norway & 21.3 & 13.46 & 34.76 \\
Portugal & 52.69 & 32.8 & 85.49 \\
Spain & & No contest on federal level & \\
Sweden & 13.13 & 69.5 & 82.63 \\
Switzerland & 48.91 & 23.61 & 72.52 \\
United & 39.86 & 14.12 & 53.98 \\
$\quad$ Kingdom & & & \\
\hline
\end{tabular}

Note: Although (as we have argued above) it is necessary to analyse the parties' policy positions separately for Flanders and Wallonia, we only report the vote shares for Belgium as a whole here, because the vote shares of the respective parties would not add up to a hundred (as both Flemish and Walloon parties compete within one election), which would make them difficult to compare to the other countries' results. 
own education, doubles (from six to 12). ${ }^{17}$ Hence, a second major finding is that over time education expansion has increasingly become a topic owned by the political left. By now, in more than six out of ten countries it is parties of the left that are the (primary) issue-owners of education expansion while education is a right-wing topic in only every fourth country.

What cannot be easily gleaned from Tables 2 and 3 is the extent to which education expansion is supported. For example, the issue may be contested because of one large issue-owner confronting a large issue-ignorer. Or, to give another example, it may be contested because of a small issue-ignorer facing a large number of primary and other issue-owners. To shed light on this issue, Table 4 contains information on the average vote share of primary and other issue-owners, which provides a rough measure for the breadth of the consensus on educational expansion. In about half of the countries (nine out of 18), the (combined) vote share of issue-owners is roughly 50 per cent, which is to be expected if the political space is equally divided between issue-owners and issue-ignorers. In some countries (notably the Netherlands, Portugal, Sweden and Switzerland, but also Iceland and Luxembourg), the (combined) vote share of issue-owners is much higher than 50 per cent, indicating a different kind of partisan conflict. In these countries, the issue of education expansion is owned by parties commanding a large vote share, whereas it is ignored by smaller parties. Ireland is an exceptional case in the sense that a very small party is the issue-owner, confronted with large issue-ignorers.

The evidence presented in Tables 4 and 2 (last column) hints at the existence of different kinds of partisan competition. The typical pattern according to Ansell (2010: 137) would be centre parties against extreme parties on the left and on the right ('inverse-U effect'). We call this pattern 'mainstream parties' against 'non-mainstream parties'. We define 'mainstream parties' as older democratic parties whose roots go back (at least) to the nineteenth century (see Lipset and Rokkan 1967) and who have a chance of becoming the largest party in a given country. Hence, mainly parties belonging to the party families of the social democrats, Christian democrats, liberals or conservatives belong to this group. All other parties (greens, fascists, etc.) are labelled as 'non-mainstream parties'. The pattern of mainstream parties owning education versus non-mainstream parties as issue-ignorers is quite common (Pattern 1a, see Table 2). It can be found in Austria, Finland, Luxembourg, Norway, Portugal, Sweden and Switzerland. We also find more exceptional cases, where nonmainstream parties are the issue-owners (Pattern 1b, see the case of Ireland which we already discussed and Flanders).

However, in contrast to Ansell (2010: 137), we also find a second general pattern, namely partisan conflict between mainstream parties of the left versus mainstream parties of the right. In these cases, it is always left parties which are the issue-owners. This pattern can be found in Denmark, Germany and Greece. In some countries, the pattern of partisan competition changes over time, usually starting with a pattern of mainstream versus non-mainstream parties, which is then transformed into a pattern of mainstream left versus 
mainstream right (Italy, Iceland and the UK). As we do not find change in the opposite direction, we can speculate that we will find this picture even more often in the future. However, identifying broad patterns of partisan competition should not make us forget that the empirical patterns can be more complex than this (over-)simplified heuristic makes us believe. To illustrate, the Netherlands and France cannot be fitted into either pattern as both countries show a combination of at least two patterns of competition.

\section{Approaching Causal Patterns: Policy Legacies and Partisan Conflict over Educational Expansion}

In this article we have presented new empirical evidence on the patterns of partisan conflict over education as well as a novel approach to analysing macro-conflict structures more generally. Our empirical results can be summarised quite succinctly. First, partisan competition over education has become more, not less contested over time (contra Jakobi 2011). Second, paralleling this development, the topic of education expansion is increasingly owned by social democratic and liberal parties. However, third, this is not a uniform trend and there remains significant variation in the cleavage structure across countries and across time. In some countries, the issue of education expansion is owned by parties of the political right - not the left. Also, partisan competition over education resembles a classical left-right conflict in some cases, whereas in others, mainstream parties of the political centre own education and non-mainstream parties ignore it.

Admittedly, the patterns of partisan competition only partly confirm our expectations with regard to the role of policy legacies. The fact that education is owned by the political right in Norway and Sweden meets our expectations with regard to the role of Protestantism and comprehensive education, but not necessarily in the cases of Switzerland, France and Flanders. Education is owned by the political left in Germany, Austria, Italy, the Netherlands, Luxembourg and Ireland, confirming our hypothesis about the role of conservative legacies in these countries. However, education is also owned by the political left in Denmark, Finland and, in the more recent period, the United Kingdom, which fits less well with our expectations. To a certain degree, this might reflect the poor operationalisation of the concept of 'educational expansion' in the CMP dataset. It simply might be too broad to capture more subtle differences between different kinds of educational reform and expansion. Clearly, more research would be welcome here. For example, using the findings from this paper as a dependent variable, we envisage conducting a 'quasi-panel' study with different sets of independent variables (partisan and religious heritage, political institutions, etc.). Alternatively, one could try to re-code party manifestos with a focus on differences in education.

Finally, although our paper is primarily addressed to scholars studying the politics of education, it is relevant for a broader audience of scholars working on parties and party competition for a number of reasons. First, we use a very 
common data set from this literature: the CMP data set. Most often the data is 'just' used to construct left-right scales and to analyse party competition on this basis. Here, we demonstrated that it is possible and fruitful to analyse single issues from the CMP data set as well (see also Nygård 2006). Future research - even when concerned with a different policy field - can make use of the methodological approach applied in the present paper. More concretely, it would be highly interesting to compare our findings for the case of educational expansion to the case of welfare state expansion (the CMP data set would allow us to do that). Our expectation would be that partisan competition in the case of welfare state expansion resembles a classical left-right pattern. Second, our article leads to a re-specification of issue-owner theories of party competition as we introduce a new concept to the party politics literature that has been overlooked so far: issue-ignoring. According to our argument, the interaction of issue-ignorers and issue-owners defines the issue character as being consensual or contested on the macro-level. Detecting issue-ignorers can help us to describe and analyse issue competition in a more analytical way. Finally, we offer a good measure to investigate (the degree of) consensus on an issue by analysing the vote share of the issue-owner(s) or issue-ignorer(s), respectively.

\section{Acknowledgements}

A previous version of this paper was presented at the Workshop 'Education, Religion and the Gender-Vote Gap' held at the University of Bremen in October 2011. We thank the participants, in particular Holger Döring, Jonathan Rodden and Torben Iversen, for their valuable input. Moreover, we thank two anonymous referees as well as the editors of WEP for helpful comments. We are grateful for valuable and keen research assistance by Anne-Sophie Fendrich and Susanne Münn. Marius R. Busemeyer and Julian L. Garritzmann gratefully acknowledge funding support from the Emmy-Noether-programme of the German Research Foundation (Grant No. BU 1852/4-1).

\section{Notes}

1. It should, however, be kept in mind that Ansell (2008) derives these expectations from a formal model which rests on a number of assumptions. Among these e.g. that parties are pure policy seekers and just represent the class-based interests of their constituencies. Hence, parties do not act strategically in order to attract voters (Ansell 2008: 205).

2. If the Manifesto Project had followed a very orthodox kind of salience theory, no positions would have been coded. But due to internal debates within the group, the coding scheme is a mixture of confrontational and salience theory. For some issues, it provides data on positive and negative mentions, such as education (positive mentions are coded in category per506 and negative mentions are coded in category per 507).

3. For reasons of simplicity, we only use the term 'Manifesto Project' or the abbreviation CMP. Officially, this project is called today MARPOR (Manifesto Research on Political Representation) and is located at the Science Centre Berlin (WZB), Germany. Its predecessor was the Comparative Manifestos Project (CMP), also located at the Science Centre. Earlier, it was 
called Manifesto Research Group (MRG) and located at the University of Essex, United Kingdom. During all these stages, the project uses (almost) the same coding procedure and (almost) the same coding categories. Data from all stages of the project are published as a unified data set on http://manifestoproject.wzb.eu/ and can be used for replication of our study.

4. Mathematically, the values of each category lie between 0 and 100 and all values of the 56 categories add up to 100 since they are percentages. Higher values mean more emphasis.

5. In the literature, we find two spellings: saliency and salience. We have decided to use the latter spelling here.

6. This category excludes technical training which is coded under 411 , the only issue that has a related topic: 'Technology and Infrastructure: Importance of modernization of industry and methods of transport and communication; importance of science and technological developments in industry; need for training and research. This does not imply education in general (see category 506). This also covers public spending on infrastructure such as streets and harbours' (Volkens et al. 2011).

7. Moreover, the CMP offers a second category for negative statements regarding education policies, i.e. 'education limitation' (item 507, defined as item 506 but negative). However, we do not use this in our analysis because, first, a negative coding does not fit into an approach grounded in salience theory (as will be shown below) and, second, because de facto hardly any party emphasises this topic (see descriptive data below).

8. We thank Torben Iversen and Jonathan Rodden for pointing this out.

9. As Belgium de facto has two party systems, namely a Wallonian and a Flemish one, we have conducted separate analysis for Wallonia and Flanders, i.e. here for French-speaking parties and Flemish-speaking parties.

10. Therefore, Spanish regionalist parties as well as the Northern Irish parties in the United Kingdom were disregarded. The Welsh Plaid Cymru is not included in the Manifesto Data set due to missing documents (Klingemann et al. 2006: 236 7). However, Plaid Cymru has no impact on national British government formation and hence can be seen as irrelevant (Sartori 1976).

11. We use the 'Full Dataset', including MPP I, MPP 2, Update 2009, Update 2010. The data set is available for free at http://manifestoproject.wzb.eu (accessed 29 August 2011). A list of the parties considered and the number of elections per country can be found in the Appendix. As the data set contains all parties that sent at least two members to parliament, all relevant parties are included.

12. The years covered are: Austria 1949 2002, Belgium 1946 2003, Denmark 1945 2005, Finland 1945 2003, France 1945 2007, Germany 1949 2009, Greece 1974 2000, Iceland 1946 1999, Ireland 1948 2007, Italy 1946 2006, Luxembourg 1945 1999, Netherlands 1946 2003, Norway 1945 2001, Portugal 1975 2009, Spain 1977 2008, Sweden 1944 2010, Switzerland 1947 2003, United Kingdom 1945 2010. For detailed information on the years included see http://manifestoproject.wzb.eu/documentation/ManifestoDataOverview2010.pdf (accessed 29 August 2011).

13. The alternative to OLS, especially when the underlying data is not normally distributed, would be a Kruskal Wallis test. The Kruskal Wallis test allows testing for group differences in the case of non-parametric data distribution.

14. Only 'Welfare Expansion', 'Social Justice', 'Environmental Protection', 'Infrastructure', 'Political Authority', 'Non-Economic Groups: Positive', and 'Democracy' show higher mean values. In case a party emphasised each of the 56 categories to the same extent, the average value was 1.79 per cent.

15. Unfortunately, we cannot analyse the descriptive statistics in further detail here. For a more indepth analysis of the descriptive data we refer to a working paper by one of us, Garritzmann (2009). Descriptive and graphical analyses available on request.

16. In Spain, however, we can detect contest between regionalist parties (which we excluded from our analysis as described above).

17. This is, of course, partly due to a larger number of cases. However, the relative numbers show as well an increase from 37 to 63 per cent. 


\section{References}

Ansell, B.W. (2008). 'University Challenges: Explaining Institutional Change in Higher Education', World Politics, 60:2, 189230.

Ansell, B.W. (2010). From the Ballot to the Blackboard: The Redistributive Political Economy of Education. New York: Cambridge University Press.

Bakker, R., E.E. Edwards, and C.E. de Vries (2006). 'Fickle Parties or Changing Dimensions? Testing the Comparability of the Party Manifesto Data across Time and Space', unpublished manuscript.

Baumgartner, F.R., S. Brouard, C. Green-Pedersen, B.D. Jones, and S. Walgrave (2011). 'The Dynamics of Policy Change in Comparative Perspective', Special Issue of Comparative Political Studies, 44:8, 9471119.

Benoit, K., and M. Laver (2006). 'Estimating Party Policy Positions: Comparing Expert Surveys and Hand-coded Content Analysis', Electoral Studies, 26, 589610.

Benoit, K., M. Laver, and S. Mikhaylov (2009). 'Treating Words as Data with Error: Uncertainty in Text Statements of Policy Positions', American Journal of Political Science, 53:2, 495513.

Boix, C. (1998). Political Parties, Growth and Equality: Conservative and Social Democratic Economic Strategies in the World Economy. Cambridge: Cambridge University Press.

Bräuninger, T., and M. Debus (2008). 'Der Einfluss von Koalitionsaussagen, programmatischen Standpunkten und der Bundespolitik auf die Regierungsbildung in den deutschen Ländern', Politische Vierteljahresschrift, 49:2, 30938.

Budge, I. (2001). 'Theory and Measurement of Party Policy Positions', in I. Budge, H.D. Klingemann, A. Volkens, J. Bara and E. Tanenbaum (eds.), Mapping Policy Preferences: Estimates for Parties, Electors, and Governments 1945 1998. Oxford: Oxford University Press, 7590.

Budge, I. (2001). 'Validating the Manifesto Research Group Approach: Theoretical Assumptions and Empirical Confirmations', in M. Laver (ed.), Estimating the Policy Position of Political Actors. London: Routledge, 5065.

Budge, I., and D.J. Farlie (1983). Explaining and Predicting Elections: Issue Effects and Party Strategies in Twenty-three Democracies. London: George Allen \& Unwin.

Budge, I., and T. Meyer (forthcoming). 'Good Data Management: Limiting Error Rather than Altering Estimates', in A. Volkens et al. (eds.), Mapping Political Preferences: Measurement Solutions for Manifesto Analysis: 54 Democracies, 1945 2012. Oxford: Oxford University Press.

Budge, I., and D. Robertson (1987). 'Do Parties Differ, and How? Comparative Discriminant and Factor Analyses: Comparative Analyses of Post-war Election Programmes', in I. Budge, D. Robertson and D. Hearl (eds.), Ideology, Strategy and Party Change: Spatial Analysis of Post-war Election Programmes in 19 Democracies. Cambridge: Cambridge University Press, 388416.

Budge, I., H.D. Klingemann, A. Volkens, J. Bara, and E. Tanenbaum, eds. (2001). Mapping Policy Preferences: Estimates for Parties, Electors, and Governments 1945 1998. Oxford: Oxford University Press.

Busemeyer, M.R. (2007). 'The Determinants of Public Education Spending in 21 OECD Democracies, 1980 2001', Journal of European Public Policy, 14:4, 582610.

Busemeyer, M.R. (2009a). 'From Myth to Reality: Globalization and Public Spending in OECD Countries Revisited', European Journal of Political Research, 48:4, 45582.

Busemeyer, M.R. (2009b). 'Social Democrats and the New Partisan Politics of Public Investment in Education', Journal of European Public Policy, 16:1, 10726.

Busemeyer, M.R. (2010). 'Redistribution and the Political Economy of Education: an Analysis of Individual Preferences in OECD Countries', Center for European Studies, Working Paper, no. 178.

Busemeyer, M.R, and R. Nikolai (2010). 'Education', in F.G. Castles, J. Lewis, H. Obinger, C. Pierson and S. Leibfried (eds.), The Oxford Handbook on Welfare State Policy. Oxford, New York: Oxford University Press, 494508.

Busemeyer, M.R., and C. Trampusch (2011). 'Review Article: Comparative Political Science and the Study of Education', British Journal of Political Science, 41:2, 41343.

Busemeyer, M.R., A. Goerres, and S. Weschle (2009). 'Attitudes towards Redistributive Spending in an Era of Demographic Ageing: The Rival Pressures from Age and Income in 14 OECD Countries', Journal of European Social Policy, 19:3, 195212. 
Busemeyer, M.R., M. Cattaneo, and S.C. Wolter (2011). 'Individual Policy Preferences for Vocational Versus Academic Education: Microlevel Evidence for the Case of Switzerland', Journal of European Social Policy, 21:3, 25373.

Castles, F.G. (1989). 'Explaining Public Education Expenditure in OECD Nations', European Journal of Political Research, 17, 43148.

Castles, F.G. (1994). 'On Religion and Public Policy: Does Catholicism make a Difference?', European Journal of Political Research, 25, 1940.

Castles, F.G. (1998). Comparative Public Policy: Patterns of Post-war Transformation. Cheltenham: Edward Elgar.

Dinas, E., and K. Gemenis (2010). 'Measuring Parties' Ideological Positions with Manifesto Data. A Critical Evaluation of the Competing Methods', Party Politics, 16:4, 42750.

Franzmann, S.T. (2011). 'Competition, Contest, and Cooperation: The Analytical Framework of the Issue-Market', Journal of Theoretical Politics, 23:3, 31743.

Franzmann, S., and A. Kaiser (2006). 'Locating Political Parties in Policy Space. A Reanalysis of Party Manifesto Data', Party Politics, 12:2, 16388.

Gabel, M., and J. Huber (2000). 'Putting Parties in their Place', American Journal of Political Science, 44:1, 94103.

Garritzmann, J.L. (2009). 'Education and Welfare: Substitutes or Complementarities?', unpublished working paper.

Green-Pedersen, C., and P.B. Mortensen (2010). 'Who Sets the Agenda and Who Responds to it in the Danish Parliament?: A New Model of Issue Competition and Agenda-setting', European Journal of Political Research, 49, 25781.

Hansen, M.E. (2008). 'Back to the Archives?: A Critique of the Danish Part of the Manifesto Dataset', Scandinavian Political Studies, 31:2, 20116.

ISSP Research Group, International Social Survey Programme (ISSP) (2006). Role of Government $I V$. Cologne: Distributor, GESIS.

Iversen, T., and J.D. Stephens (2008). 'Partisan Politics, the Welfare State, and Three Worlds of Human Capital Formation', Comparative Political Studies, 41:4 5, 60037.

Jakobi, A.P. (2011). 'Political Parties and the Institutionalization of Education: A Comparative Analysis of Party Manifestos', Comparative Education Review, 55:2, 189209.

Jakobi, A.P., K. Martens, and K.D. Wolf, eds. (2009). Education in Political Science. Discovering a Neglected Field. London: Routledge.

Jensen, C. (2009). 'Partisan Politics turned Upside Down: Tertiary Education as Social Protection against De-industrialization', available at http://ssrn.com/abstract 1460031 (accessed 4 January 2012).

Jensen, C. (2011). 'Capitalist Systems, Deindustrialization, and the Politics of Public Education', Comparative Political Studies, 44:4, 41235.

Kittel, B., and H. Obinger (2003). 'Political Parties: Institutions, and the Dynamics of Social Expenditure in Times of Austerity', Journal of European Public Policy, 10:1, 2045.

Klingemann, H.D. (1995). 'Party Positions and Voter Orientations', in H.D. Klingemann and D. Fuchs (eds.), Citizens and the State. Oxford: Oxford University Press, 183205.

Klingemann, H.D., A. Volkens, J. Bara, I. Budge, and M. McDonald, eds. (2006). Mapping Policy Preferences II: Estimates for Parties, Electors, and Governments in Eastern Europe, European Union, and OECD 1990 2003. Oxford, New York: Oxford University Press.

Klitgaard, M.B. (2007). 'Do Welfare State Regimes Determine Public Sector Reforms? Choice Reforms in American, Swedish and German Schools', Scandinavian Political Studies, 30:4, 44468.

Laver, M., and K. Benoit (2007). 'Estimating Party Policy Positions: Comparing Expert Surveys and Hand-coded Content Analysis', Electoral Studies, 26:1, 90107.

Laver, M., and I. Budge (1992). 'Measuring Policy Distances and Modelling Coalition Formation', in M. Laver and I. Budge (eds.), Party Policy and Government Coalitions. New York: St. Martins Press, 1540.

Laver, M., and J. Garry (2000). 'Estimating Policy Positions from Political Texts', American Journal of Political Science, 44, 61934. 
Laver, M., K. Benoit, and J. Garry (2003). 'Extracting Policy Positions from Political Text Using Words as Data', American Political Science Review, 97:2, 31131.

Lipset, S.M., and S. Rokkan (1967). Party Systems and Voter Alignments: Cross-national Perspectives. New York: Free Press.

Lowe, W., K. Benoit, S. Mikhaylov, and M. Laver (2011). 'Scaling Policy Positions from Coded Units of Political Texts', Legislative Studies Quarterly, 36:1, 12355.

Manow, P., and K. van Kersbergen (2009). 'Religion and the Western Welfare State The Theoretical Context', in K. van Kersbergen and P. Manow (eds.), Religion, Class Coalitions, and Welfare States. New York: Cambridge University Press, 138.

McDonald, M.D., and S.M. Mendes (2001). 'The Policy Space of Party Manifestos', in M. Laver (ed.), Estimating the Policy Position of Political Actors. London: Routledge, 90114.

Meguid, B.M. (2008). Competition between Unequals: Strategies and Electoral Fortunes in Western Europe. Cambridge: Cambridge University Press.

Meyer, J.W., J. Boli, G.M. Thomas, and F.O. Ramirez (1997). 'World Society and the Nation State', American Journal of Sociology, 103:1, 14481.

Nygård, M. (2006). 'Welfare-ideological Change in Scandinavia: A Comparative Analysis of Partisan Welfare-Policy Positions in Four Nordic Countries 1970 2003', Scandinavian Political Studies, 29:4, 35685 .

Oftedal Telhaug, A., O. Asbjørn Mediås, and P. Aasen (2006). 'The Nordic Model in Education: Education as Part of the Political System in the Last 50 Years', Scandinavian Journal of Educational Research, 50:3, 24583.

Pelizzo, R. (2003). 'Party Positions or Party Direction? An Analysis of Party Manifesto Data', West European Politics, 26:2, 6789.

Robertson, D. (1976). A Theory of Party Competition. London: John Wiley \& Sons.

Sartori, G. (1976). Parties and Party Systems. Cambridge: Cambridge University Press.

Schmidt, M.G. (2007). 'Testing the Retrenchment Hypothesis: Educational Spending, 1960 2002', in F.G. Castles (ed.), The Disappearing State? Retrenchment Realities in an Age of Globalization. Cheltenham, Northampton: Edward Elgar, 15983.

Schmitt, R. (2008). 'Die politikfeldspezifische Auswertung von Wahlprogrammen am Beispiel der deutschen Bundesländer', working paper, Mannheimer Zentrum für Europäische Sozialforschung.

Slapin, J., and S.O. Proksch (2008). 'A Scaling Model for Estimating Time Series Party Positions from Texts', American Journal of Political Science, 52:3, 70522.

Smith, G. (1988). 'Between Left and Right: The Ambivalence of European Liberalism', in E.J. Kirchner (ed.), Liberal Parties in Western Europe. Cambridge: Cambridge University Press, 1628.

Steed, M., and P. Humphreys (1988). 'Identifying Liberal Parties', in E.J. Kirchner (ed.), Liberal Parties in Western Europe. Cambridge: Cambridge University Press, 396435.

Stokes, D. (1992). 'Valence Politics', in K. Dennis (ed.), Electoral Politics. Oxford: Clarendon Press, 14162.

Volkens, A. (2006). 'Policy Changes of Parties in European Parliament Party Groups', in J. Bara and A. Weale (eds.), Democratic Politics and Party Competition: Essays in Honour of Ian Budge. London, New York: Routledge, 5681.

Volkens, A. (2007). 'Strengths and Weaknesses of Approaches to Measuring Policy Positions of Parties', Electoral Studies, 26:1, 10820.

Volkens, A. (2009). 'Die Daten des Comparative Manifestos Project', in K.U. Schnapp, N. Behnke and J. Behnke (eds.), Datenwelten: Datenerhebung und Datenbestände in der Politikwissenschaft. Nomos: Baden-Baden, 2719.

Volkens, A., O. Lacewell, S. Regel, H. Schultze, and A. Werner (2011). The Manifesto Data Collection: Manifesto Project (MRG/CMP/MARPOR). Berlin: Wissenschaftszentrum Berlin für Sozialforschung (WZB).

Walgrave, S., and M. Nuytemans (2009). 'Friction and Party Manifesto Change in 25 Countries', American Journal of Political Science, 53:1, 190206. 
West, M.R., and L. Woessmann (2010). 'Every Catholic Child in a Catholic School: Historical Resistance to State Schooling: Contemporary Private Competition and Student Achievement Across Countries', The Economic Journal, 120:546, F229 55.

Wolf, F. (2006). Die Bildungsausgaben der Bundesländer im Vergleich: Welche Faktoren erklären ihre beträchtliche Variation? Münster: LIT Verlag.

Wolf, F., and R. Zohlnhöfer (2009). 'Investing in Human Capital? The Determinants of Private Education Expenditure in 26 OECD Countries', Journal of European Social Policy, 19:3, 23044.

APPENDIX

TABLE A

DESCRIPTIVE STATISTICS

\begin{tabular}{|c|c|c|c|c|}
\hline \multicolumn{4}{|c|}{ Manifestos per country } & \multirow[b]{2}{*}{ Parties considered } \\
\hline Country & $\begin{array}{l}\text { Number of } \\
\text { manifestos }\end{array}$ & $\begin{array}{l}\text { Share of each } \\
\text { country's } \\
\text { manifestos in } \\
\text { data set }(\%)\end{array}$ & $\begin{array}{l}\text { Number of } \\
\text { elections }\end{array}$ & \\
\hline Austria & 59 & 3.3 & 17 & Green, SPÖ, FPÖ, LF, ÖVP \\
\hline Belgium & 140 & 7.8 & 19 & $\begin{array}{l}\text { Wallonia: ECOLO, PSB-BSP, } \\
\text { PS, PVV-PLP, PRL, PLDP, } \\
\text { PSC-CVP, PSC, RW, FDF. } \\
\text { Flanders: AGALEV, PSB-BSP, } \\
\text { SP, PVV-PLP, VLD, CVP, VU, } \\
\text { VB }\end{array}$ \\
\hline Denmark & 215 & 12.1 & 25 & $\begin{array}{l}\text { VS, DKP, EL, SF, SD, CD, RV, } \\
\text { V, DU, KRF, FK, DF, FP, RF }\end{array}$ \\
\hline Finland & 127 & 7.1 & 17 & $\begin{array}{l}\text { Vlgreen, SKDL, VL, TPSL, } \\
\text { SSDP, LKP, SKL, KK, SK, PS, } \\
\text { SFP }\end{array}$ \\
\hline France & 93 & 5.2 & 16 & $\begin{array}{l}\text { Greens, PCF, PS, ERRS, MRP, } \\
\text { CD, Gaullists, Conservatives, } \\
\text { UDF, RPR, UMP, FN }\end{array}$ \\
\hline Germany & 70 & 3.9 & 17 & $\begin{array}{l}\text { Greens, PDS/Linke, SPD, FDP, } \\
\text { CDU/CSU, DZ Zentrum, DP } \\
\text { German Party }\end{array}$ \\
\hline Greece & 36 & 2.0 & 10 & $\begin{array}{l}\text { KKE, SAP, PASOK, EDIK, ND, } \\
\text { POLA }\end{array}$ \\
\hline Iceland & 81 & 4.5 & 17 & $\begin{array}{l}\text { VGF, AD, A, SFVM, S, FF, SJ, } \\
\text { F, KV }\end{array}$ \\
\hline Ireland & 86 & 4.8 & 18 & $\begin{array}{l}\text { Greens, WP, DLP, PD, FG, FF, } \\
\text { CNP, CNT, SF }\end{array}$ \\
\hline Italy & 133 & 7.5 & 16 & $\begin{array}{l}\text { FDV, PDUP, DP, RC, PDCI, } \\
\text { DS, Sgarbi-Panella, PSI, } \\
\text { OliveTree, PSDI, PRI, PLI, PPI, } \\
\text { AD, FI, } \\
\text { NewItalianSocialistParty, AN, } \\
\text { LN, LDV, LR }\end{array}$ \\
\hline Luxembourg & 58 & 3.3 & 13 & $\begin{array}{l}\text { GLEI, GAP, GLEIGAP, PCL- } \\
\text { KPL, POSL-LSAP, PD-DP, } \\
\text { PCS-CSV, ADR }\end{array}$ \\
\hline Netherlands & 106 & 5.9 & 18 & $\begin{array}{l}\text { GL, SP, PPR, PVDA, D66, } \\
\text { VVD, CDA, KVP, ARP, DS70, } \\
\text { CHU }\end{array}$ \\
\hline
\end{tabular}

(Continued) 
TABLE A1 (Continued)

\begin{tabular}{|c|c|c|c|c|}
\hline \multicolumn{4}{|c|}{ Manifestos per country } & \multirow[b]{2}{*}{ Parties considered } \\
\hline Country & $\begin{array}{l}\text { Number of } \\
\text { manifestos }\end{array}$ & $\begin{array}{l}\text { Share of each } \\
\text { country's } \\
\text { manifestos in } \\
\text { data set }(\%)\end{array}$ & $\begin{array}{l}\text { Number of } \\
\text { elections }\end{array}$ & \\
\hline Norway & 98 & 5.5 & 15 & $\begin{array}{l}\text { NKP, SV, DNA, DLF, V, KRF, } \\
\text { H, SP, FRP }\end{array}$ \\
\hline Portugal & 88 & 4.9 & 13 & $\begin{array}{l}\text { Green, UDP, BE, PSP, CDU, } \\
\text { MDP, PSP, PRD, PSD, PP }\end{array}$ \\
\hline Spain & 104 & 5.8 & 10 & $\begin{array}{l}\text { IU, PSOE, UCD, PDP, CDS, } \\
\text { PP, CIU, EE, PNV-EAJ, EA, } \\
\text { PAR, ECR, PA, CC, BNG, } \\
\text { CHA, UPN }\end{array}$ \\
\hline Sweden & 119 & 6.7 & 21 & $\begin{array}{l}\text { Green, VP, SDAP, FP, KDS, } \\
\text { MSP, CP }\end{array}$ \\
\hline Switzerland & 114 & 6.4 & 15 & $\begin{array}{l}\text { GPS-PES, PDA, SPS-PSS, } \\
\text { LDU-ADJ, FDP-PRD, CVP- } \\
\text { PDC, EVP-PEP, LPS-PLS, SD, } \\
\text { EDU, SVP-UDC, FPS }\end{array}$ \\
\hline $\begin{array}{l}\text { United } \\
\text { Kingdom }\end{array}$ & 57 & 3.2 & 18 & Lab, Cons, Lib(dem), SNP \\
\hline Total & 1784 & 100 & 295 & \\
\hline
\end{tabular}

Source: Own calculations based on CMP data.

TABLE A 2

DESCRIPTIVE COUNTRY SUMMARIES FOR EDUCATION EXPANSION (PER506) AND EDUCATION LIMITATION (PER507)

\begin{tabular}{lcccccccc}
\hline Country & $\begin{array}{c}\text { Mean } \\
\mathbf{5 0 6}\end{array}$ & $\begin{array}{c}\text { SD } \\
\mathbf{5 0 6}\end{array}$ & $\begin{array}{c}\text { Mean 506 } \\
\text { (weighted) }\end{array}$ & $\begin{array}{c}\text { SD 506 } \\
\text { (weighted) }\end{array}$ & $\begin{array}{c}\text { Mean } \\
\mathbf{5 0 7}\end{array}$ & $\begin{array}{c}\text { SD } \\
\mathbf{5 0 7}\end{array}$ & $\begin{array}{c}\text { Mean 507 } \\
\text { (weighted) }\end{array}$ & $\begin{array}{c}\text { SD 507 } \\
\text { (weighted) }\end{array}$ \\
\hline Austria & 3.80 & 4.17 & $\mathbf{4 . 0 6}$ & 3.75 & 0.09 & 0.68 & $\mathbf{0 . 1 4}$ & 0.83 \\
Belgium & $\mathbf{3 . 5 2}$ & 2.86 & 3.50 & 2.73 & 0.02 & 0.11 & $\mathbf{0 . 0 4}$ & 0.13 \\
Denmark & 2.89 & 4.19 & $\mathbf{3 . 3 5}$ & 4.32 & 0.13 & 0.53 & 0.13 & 0.52 \\
Finland & 2.91 & 3.42 & $\mathbf{3 . 2 6}$ & 3.86 & 0.06 & 0.56 & $\mathbf{0 . 0 8}$ & 0.64 \\
France & 4.35 & 2.68 & $\mathbf{4 . 6 1}$ & 2.72 & $\mathbf{0 . 0 5}$ & 0.35 & 0.02 & 0.25 \\
Germany & $\mathbf{3 . 8 1}$ & 3.22 & 3.57 & 3.04 & 0.02 & 0.09 & 0.02 & 0.08 \\
United & 3.83 & 2.58 & $\mathbf{3 . 9 4}$ & 2.47 & 0.10 & 0.22 & $\mathbf{0 . 1 2}$ & 0.24 \\
$\quad$ Kingdom & & & & & & & & \\
Greece & 3.37 & 3.18 & $\mathbf{3 . 7 9}$ & 3.37 & 0.00 & 0.00 & 0.00 & 0.00 \\
Iceland & 2.97 & 3.21 & $\mathbf{3 . 0 3}$ & 3.17 & 0.00 & 0.00 & 0.00 & 0.00 \\
Ireland & $\mathbf{3 . 8 8}$ & 2.91 & 3.21 & 2.47 & 0.16 & 1.49 & $\mathbf{0 . 3 8}$ & 2.25 \\
Italy & 3.12 & 2.93 & $\mathbf{3 . 5 2}$ & 2.91 & 0.07 & 0.37 & 0.06 & 0.31 \\
Luxembourg & 5.01 & 4.63 & $\mathbf{5 . 7 5}$ & 4.97 & 0.01 & 0.05 & 0.01 & 0.05 \\
Netherlands & 4.21 & 2.27 & $\mathbf{4 . 4 2}$ & 2.23 & $\mathbf{0 . 1 2}$ & 0.29 & 0.09 & 0.25 \\
Norway & 6.41 & 2.87 & $\mathbf{6 . 7 0}$ & 2.78 & $\mathbf{0 . 0 7}$ & 0.22 & 0.04 & 0.15 \\
Portugal & 4.01 & 3.89 & $\mathbf{4 . 7 2}$ & 4.30 & $\mathbf{0 . 0 2}$ & 0.09 & 0.01 & 0.06 \\
Spain & 3.52 & 1.93 & $\mathbf{3 . 9 4}$ & 1.72 & 0.00 & 0.00 & 0.00 & 0.00 \\
Sweden & 4.09 & 3.53 & $\mathbf{4 . 6 9}$ & 3.54 & 0.01 & 0.14 & 0.01 & 0.15 \\
Switzerland & 3.10 & 2.60 & $\mathbf{3 . 3 2}$ & 2.54 & $\mathbf{0 . 1 2}$ & 0.37 & 0.07 & 0.28 \\
\hline
\end{tabular}

Source: Own calculations based on CMP data. SD Standard Deviation. The columns labelled 'weighted' report data weighted by the vote share of each party. Numbers in bold indicate whether the weighted or unweighted data shows higher levels. 